\title{
エネルギーと地球環境 についての考察
}

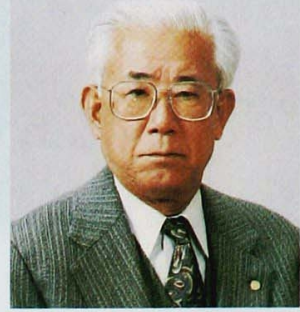

エネルギー資源としてだれでもがご存じのものは，石 油, 石炭, 天然ガス，ウラン燃料，樹木，わら，乾草，河 川や湖の水ということになる。雨や雪は水資源であるの で，エネルギー資源の仲間に入ることになろう。近年は， 都市の住人, 工場等から排出されるゴミなどが火力発電所 の燃料として使われるということである。その他に，海の 干満の差を利用した潮力発電所がフランスに設立されてい るが，わが国ではかつて，有明湾ではどうかというくらい であった。上述の資源のうち今日人数が頼りにしてきたの は, 石炭, 石油, 天然ガスの化石燃料, 水力, ウラン燃料 である。

ここで過去を振り返ってみると，1965 年ごろからのわ が国の高度経済成長期には, 東京湾, 大阪湾, 伊勢湾など に工場群が進出し, 特に大型の石油化学工場, 大容量の火 力発電所が設置されて石油を燃料としていたため,これら 湾の周辺の大気は酸や窒素酸加物で污染されることになっ た。そこで政府は，工場，発電所に対して脱硫，脱硝の装 置を設置するよう規制した結果，次第に大気は以前の状態 に戻ってきた。

かつて所用で，中国の東北地区の潘陽の近くの工場街に 出かけたが，車の中から見た街は昼間だというのに薄暗 く，車を下りたとき鼻をついたのは，石炭のくすぶってい る臭気だった。この様子では，風の方向によってはわが国 にも酸性雨が降り, 森林の樹木や湖の魚類がやがては死に 絶えるのではないかと思ったものだ。

またその後, 欧州に出張してフィンランドの電力会社を 訪ねたとき，この国の湖には魚がいないと聞いた。また西 独の森は樹木が多数枯れていたが，いずれも酸性雨のため だという。そのとき「日本はどうだ」というので，「わが 国には脱硫，脱硝装置が火力発電所などに設置されている から，その心配はない」と申し上げたところ，先方は「日 本の脱硫, 脱硝装置のことは聞いている。性能がすばらし いことは知っている」ということであった。

化石燃料は燃焼による排ガスで大気を污染するというこ とは，皆様はよくご存じであったが，1945 年 8 月の広島 と長崎への原子爆弾の投下は, 多数の死傷者を出したこ
と，街の破壊と放射能污染を受けたことからの原子力に対 する反対が強かったが，将来の燃料問題を考慮されてか， 次第に原子力発電も見守る姿勢に変化したように思う。そ こで 1966 年 7 月に日本原電(株) の東海発電所が運開, 次 に関西電力 (株)の美浜発電所の 1 号機が 1970 年 11 月 28 日に運開，東京電力 (株)福島第一原子力発電所 1 号機が 1971 年 3 月 26 日に運開し, 原子力発電が電力供給の責務 を果たすことになった。

今日の地球上の人口は約 53 億人という。今後の人口増 加は開発途上国が主であろう。先進諸国の人口は大体がや や減少の途をたどるだろうが，地球上の人口は今後とも増 加するであろう。したがってエネルギーの消費量が減少す るとは考えられず，エネルギー消費に伴う環境問題は今後 も見守る必要がある。

かくして, 今後の問題としては, エネルギー資源として の化石燐料, ウラン燃料の供給はいつまでかということに なる。そこで地球とエネルギー資源，特に化石燃料につい て考察してみたい。

化石燃料は今から 3 億 7 千万年から 3 億 2 千万年前の石 炭紀に生成されたのではないかという説がある。当時の大 気は，ソ連のブディコ博士等によると $\mathrm{CO}_{2}$ は 2,990 (ppm) であったという。お茶の水女子大学の内嶋教授に よると, そのころ地球内部でマントルの対流が活発化し, 火山の爆発が相次いで起こり，炭酸ガスが大量に放出され たという。そのため大気は $\mathrm{CO}_{2}$ で充満していて，地球上 はちょうど蒸し風呂のように高温多湿であったという。 したがってシダ類が生成，繁茂し，今日では高さが $1 \mathrm{~m}$ ほ どのシダ類が幹の周り $1 \mathrm{~m}$ ほど, 高さが $20 \sim 30 \mathrm{~m}$ という 大森林が地球各所に生成して, 今日の石炭となっている。 また，このころの湖や海の入り江には，各種の魚類が多量 に育ち，それらが地盤の変動で埋没し，地熱等によって石油 や天然ガスが地中深く生成されたのではないかと思う。

かかる考え方をして来ると，地球の自然摂理は，われら 人類のために種々配慮して下さっているとも考えられる。 また私は今後, これらの事項と, 豊富な水から水素を安く 多量につくり出すことを考究して行くことにしている。 